\title{
Targeting HIF2 in Clear Cell Renal Cell Carcinoma
}

\author{
Hyejin Cho and William G. Kaelin \\ Howard Hughes Medical Institute, Dana-Farber Cancer Institute and Brigham and Women's Hospital, \\ Harvard Medical School, Boston, Massachusetts 022145 \\ Correspondence: william_kaelin@dfci.harvard.edu
}

\begin{abstract}
Inactivation of the von Hippel-Lindau tumor-suppressor protein (pVHL) is the signature "truncal" event in clear cell renal cell carcinoma, which is the most common form of kidney cancer. pVHL is part of a ubiquitin ligase the targets the $\alpha$ subunit of the hypoxia-inducible factor (HIF) transcription factor for destruction when oxygen is available. Preclinical studies strongly suggest that deregulation of HIF, and particularly HIF2, drives pVHL-defective renal carcinogenesis. Although HIF $2 \alpha$ was classically considered undruggable, structural and chemical work by Rick Bruick and Kevin Gardner at University of Texas Southwestern laid the foundation for the development of small molecule direct HIF2 $\alpha$ antagonists (PT2385 and the related tool compound PT2399) by Peloton Therapeutics that block the dimerization of HIF2 $\alpha$ with its partner protein ARNT1. These compounds inhibit clear cell renal cell carcinoma growth in preclinical models, and PT2385 has now entered the clinic. Nonetheless, the availability of such compounds, together with clustered regularly interspaced short palindromic repeat (CRISPR)-based gene editing approaches, has revealed a previously unappreciated heterogeneity among clear cell renal carcinomas and patient-derived xenografts with respect to HIF2 dependence, suggesting that predictive biomarkers will be needed to optimize the use of such agents in the clinic.
\end{abstract}

Epithelial cancers, such as breast, lung, and colon cancer, account for most cancer deaths in the developed world. Accordingly, it is imperative that we make strides toward preventing and treating such cancers if we are going to significantly decrease cancer mortality in countries such as the United States. Kidney cancer is an epithelial cancer and in the United States is one of the 10 most common cancers in men and women and one of the 10 most common causes of cancer deaths in men (Siegel et al. 2016). Kidney cancer can be subdivided based on its histological appearance into clear cell renal cell carcinoma, which is by far the most common form of kidney cancer, papillary renal cell carcinoma, chromophobe renal cell carcinoma, collecting duct, and a few other variants. This review will discuss the role of the von Hippel-Lindau (VHL) tumor-suppressor protein ( $\mathrm{pVHL}$ ) and the HIF2 transcription factor in clear cell renal cell carcinoma and recent progress toward targeting HIF2 with drug-like small molecules.

\section{CLEAR CELL RENAL CELL CARCINOMA GENETICS}

Rare hereditary forms of cancer have often been informative with respect to the genetics of sporadic cancers. VHL disease presents as a hereditary cancer syndrome characterized by an increased risk of clear cell renal cell carcinoma, blood vessel tumors called hemangioblastomas, and adrenal gland tumors called pheochromocytomas (Maher and Kaelin 1997; Kaelin 2002). Individuals with VHL disease have inherited a defective version of the $V H L$ gene, which resides at chromosome $3 \mathrm{p} 25$, from one of their parents or acquired a de novo mutation, resulting in heterozygosity or mosaicism, respectively, at the VHL locus. Tumors develop when the remaining wild-type $V H L$ alleles are mutated, deleted, or otherwise silenced in a susceptible cell. Importantly, biallelic $V H L$ inactivation is also extremely common $(>50 \%)$ in sporadic clear cell renal cell carcinomas. The actual prevalence might be significantly higher if one excludes clear cell renal carcinomas with atypical histological features and uses state of the art DNA sequencing methods. In sporadic clear cell renal carcinoma, inactivation of the maternal and paternal VHL alleles is caused by sporadic mutations (in contrast to classical VHL disease, where the first mutation or "hit" has been inherited), including point mutations and deletions or, less commonly, hypermethylation.

Although biallelic $V H L$ inactivation is a common, and possibly nearly universal, first step in clear cell renal carcinogenesis, it is not sufficient to cause this disease. This has been most clearly shown by careful studies of kidneys from VHL patients, which can contain hundreds of small dysplastic lesions and cysts. Genotyping such lesions reveals biallelic VHL inactivation (Walther et al.

(C) 2016 Cho and Kaelin. This article is distributed under the terms of the Creative Commons Attribution-NonCommercial License, which permits reuse and redistribution, except for commercial purposes, provided that the original author and source are credited. 
1995; Zhuang et al. 1995; Lubensky et al. 1996; Mandriota et al. 2002; Montani et al. 2010). It therefore appears that $V H L$ loss is sufficient to cause renal dysplasia but not cancer. The same appears to be true in genetically engineered mouse models (Gnarra et al. 1997; Frew et al. 2008; Schietke et al. 2012; Albers et al. 2013). Another line of evidence has come from genomic analyses of hereditary (VHL disease) and sporadic clear cell renal carcinomas to identify recurrent mutations, including intragenic mutations and copy-number changes (Beroukhim et al. 2009; Guo et al. 2011; Varela et al. 2011; Dondeti et al. 2012; Duns et al. 2012; Pena-Llopis et al. 2012; Cancer Genome Atlas Research Network 2013). Clear cell renal carcinomas typically include specific copy-number changes, most commonly gain of chromosome $5 q$, loss of chromosomes $3 p$ and $14 q$, and specific intragenic mutations affecting genes linked to chromatin regulation, phosphoinositide 3-kinase (PI3K) signaling, and response to redox stress or DNA damage. Examples of such genes include PBRM1, BAP1, SETD2, KDM5C, TSC1, PIK3CA, PTEN, MTOR, and TP53. Importantly, inactivation of $V H L$ has preceded the acquisition of these other mutations in every tumor examined to date in which deep sequencing of spatially distinct sites was used to infer its evolutionary history (Gerlinger et al. 2012, 2014; Xu et al. 2012; Fisher et al. 2014; Sankin et al. 2014). These studies have confirmed that VHL inactivation is an early, or "truncal," lesion in clear cell renal cell carcinomas and that such tumor often display significant heterogeneity, or "branching," with respect to the subsequent genetic events that conspired with $V H L$ loss to cause cancer. Interestingly, VHL, $P B R M 1, B A P 1$, and SETD2 all reside on chromosome $3 \mathrm{p}$. Therefore three "hits," including two intragenic mutations and loss of chromosome $3 \mathrm{p}$, can inactivate both $V H L$ and another "Knudson 2-hit" renal cancer suppressor. For reasons that are still not well understood, VHL mutations are exceedingly rare in other neoplasms with the exceptions of pheochromocytomas and hemangioblastomas.

\section{THE VHL TUMOR-SUPPRESSOR PROTEIN}

The VHL gene encodes two different proteins, with apparent molecular mass of $\sim 28 \mathrm{kDa}$ and $19 \mathrm{kDa}$ after sodium dodecyl sulfate-polyacrylamide gel electrophoresis (SDS-PAGE), because of alternative in-frame translational start sites (Kaelin 2007). For simplicity let us refer to both of these as pVHL in this review, because their functions appear to be highly similar, and disease-associated VHL mutations almost invariably affect both isoforms. pVHL can be found in both the cytoplasm and the nucleus, shuttling dynamically between the two compartments (Kaelin 2007). Some pVHL can also be detected associated with membranes, the endoplasmic reticulum, and mitochondria (Kaelin 2007).

Reintroducing wild-type pVHL into pVHL-defective clear cell renal carcinoma lines suppresses their ability to form tumors in nude mice xenograft assays but does not affect their viability or proliferation under standard cell culture conditions (Iliopoulos et al. 1995). pVHL does inhibit pVHL-defective clear cell renal carcinoma cells ex vivo, however, under specific conditions such as when such cells are grown as three-dimensional spheroids or at confluence under growth factor-poor conditions (Lieubeau-Teillet et al. 1998; Pause et al. 1998; Davidowitz et al. 2001).

pVHL is the substrate adapter of a ubiquitin ligase that contains elongin $\mathrm{B}$, elongin $\mathrm{C}, \mathrm{Rbx} 1$, and Cullin-2 (Kaelin 2007). pVHL has two domains that are hotspots for missense mutations in VHL disease: the $\alpha$ domain, which recruits the ubiquitination machinery, and the $\beta$ domain, which serves as a substrate docking site. Although many potential pVHL substrates have been identified, the best documented substrate, and the one believed to be most tightly linked to clear cell renal carcinogenesis, is the HIF (hypoxia-inducible factor) transcription factor.

\section{THE HIF TRANSCRIPTION FACTOR}

Active HIF is a heterodimer of two basic helix-loophelix PAS domain-containing DNA-binding proteins, an unstable $\alpha$ subunit and a stable $\beta$ subunit, and binds to specific DNA sequences called hypoxia-response elements (HREs) (Kaelin and Ratcliffe 2008; Semenza 2011). The human genome contains three $H I F \alpha$ genes (HIF $1 \alpha$, HIF $2 \alpha$, HIF3 $\alpha$ ) and two HIF $\beta$ genes (HIF1 $\beta$, also called ARNT1, and HIF2 $\beta$, also called ARNT2). HIF $1 \alpha$ is widely expressed and, together with HIF $1 \beta$, forms the well-studied, canonical, HIF transcription factor. The expression of HIF $2 \alpha$ is more restricted. HIF $1 \alpha$ and HIF $2 \alpha$ each contain two transactivation domains, an amino-terminal transactivation domain (NTAD) and carboxy-terminal transactivation domain (CTAD), that enable them, upon DNA-binding, to recruit coactivators such as p300 and CREB-binding protein (CBP) and activate transcription. HIF3 $\alpha$ has been far less studied, but encodes multiple splice variants that do not activate transcription but instead act as dominant-negative inhibitors of HIF-dependent transcription.

HIF regulates hundreds of genes, many of which play roles in acute or chronic adaptation to hypoxia. HIF regulates genes linked to processes such as anaerobic glycolysis, mitochondrial biosynthesis and function, autophagy, angiogenesis, cell proliferation, invasion, and migration (Fig. 1). The ability of HIF to activate some HRE-containing HIF target genes is highly cell type- and contextdependent, presumably because of the influence of other cis-acting transcription factors as well as changes in chromatin accessibility. For example, vascular endothelial growth factor (VEGF) responds to HIF in many tissues, whereas erythropoietin (EPO) in adults responds to HIF largely in dedicated cells in the kidney. Likewise, the sets of genes regulated by HIF1 and HIF2, although overlapping, are not identical. For example, some glycolytic and autophagy genes are primarily regulated by HIF1, whereas EPO is primarily regulated by HIF2 (Hu et al. 2003; Rankin et al. 2007; Kapitsinou et al. 2010). 


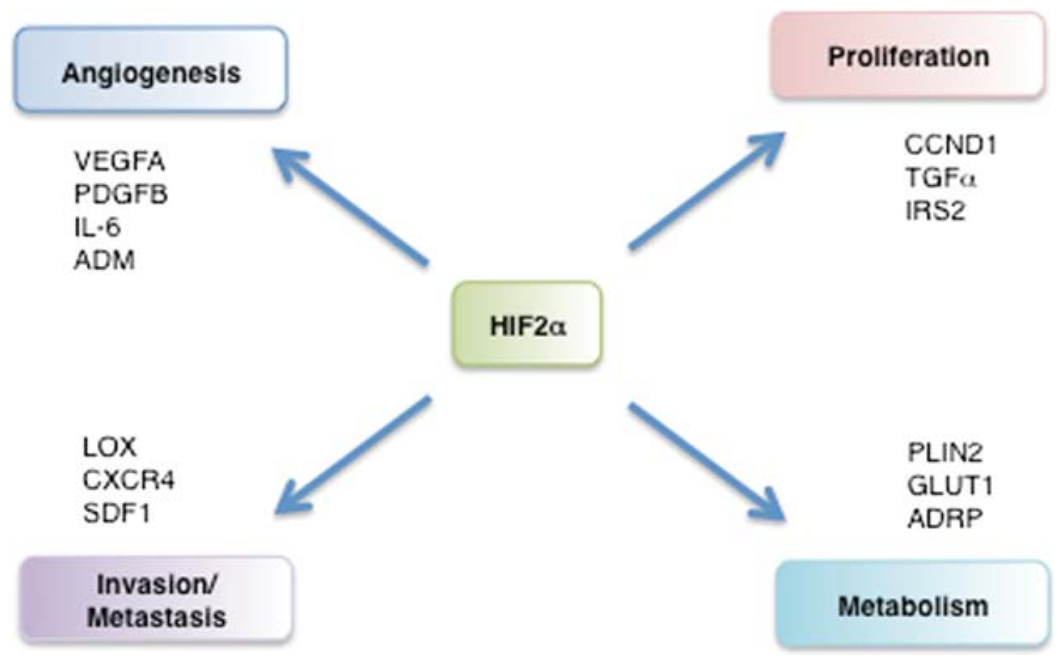

Figure 1. Hypoxia-inducible factor 2 (HIF2)-regulated biological processes germane to kidney cancer. Examples of HIF2-responsive mRNAs linked to biological processes implicated in renal carcinogenesis are shown.

\section{REGULATION OF HIF BY pVHL AND OXYGEN}

Under well-oxygenated conditions HIF $\alpha$ is prolyl-hydroxylated on one (or both) of two potential prolyl residues by members of the EgIN (also called PHD) prolyl hydroxylase family, which serve as oxygen sensors (for review, see Kaelin and Ratcliffe 2008). Once prolyl-hydroxylated, HIF $\alpha$ binds directly to the pVHL ubiquitin ligase complex and is targeted for proteasomal degradation. Under low-oxygen conditions EgIN activity is impaired, which allows HIF $\alpha$ to accumulate, bind to HIF $\beta$, and activate transcription. Another layer of oxygen-dependent HIF regulation is provided by the FIH1 asparaginyl hydroxylase. In the presence of oxygen FIH1 hydroxylates a conserved asparaginyl residue located within the HIF $\alpha$ CTAD, preventing it from binding to coactivators. Importantly, FIH1 has a higher oxygen affinity than the EgINs, and thus can remain active at intermediate levels of hypoxia that are sufficient to stabilize $H I F \alpha$. Some HIF-responsive genes depend primarily on the NTAD and others on the CTAD. Moreover, the HIF $2 \alpha$ is relatively resistant to FIH1. Therefore, FIH1 can potentially tune the HIF response at intermediate levels of hypoxia by altering the balance of NTAD and CTAD function and possibly the balance of HIF1 and HIF2 activity.

\section{ROLE OF HIF2 IN CLEAR CELL RENAL CARCINOGENESIS}

Multiple lines of evidence suggest that HIF, and particularly HIF2, is a critical target in clear cell renal cell carcinoma. Every VHL mutation linked to clear cell renal carcinoma to date results in a protein that is defective with respect to HIF regulation, and genotype-phenotype correlations suggest that the risk of developing clear cell renal carcinoma in VHL disease families is linked to the degree to which their $V H L$ alleles compromise
pVHL's ability to suppress HIF (Li et al. 2007; Kaelin 2008). In particular, VHL families with a low risk of developing clear cell renal carcinoma, even if at high risk of hemangioblastomas and pheochromocytomas, have $V H L$ alleles that encode proteins that retain significant HIF ubiquitin ligase activity, whereas families at high risk of clear cell renal carcinoma are grossly defective in this regard (Kaelin 2008).

In the laboratory, activating HIF2-responsive genes, such as by expressing a HIF2 $\alpha$ variant that cannot be prolyl-hydroxylated, can override pVHL's tumor-suppressor activity in nude mice xenograft assays (Kondo et al. 2002; Raval et al. 2005; Biswas et al. 2010). Conversely, down-regulating HIF $2 \alpha$ with short-hairpin RNA (shRNA) technology suppresses tumor formation by pVHL-defective clear cell renal carcinomas in mice (Kondo et al. 2003; Zimmer et al. 2004; Gordan et al. 2008).

Currently there are no faithful, highly penetrant, genetically engineered mouse models for $V H L^{-/-}$clear cell renal carcinomas. Nonetheless, the pathological changes induced after inactivating VHL in various mouse tissues has, when tested, been prevented by concurrent inactivation of HIF2 $\alpha$ (Rankin et al. 2007, 2008, 2009) and can, when tested, be mimicked by expressing a version of HIF $2 \alpha$ that cannot be prolyl-hydroxylated in wild-type mice (Kim et al. 2006). Notably, a human genetic polymorphism linked to HIF $2 \alpha$ is associated with the risk of developing clear cell renal cell carcinoma (Purdue et al. 2011).

In stark contrast HIF $1 \alpha$ appears capable of suppressing clear cell renal carcinomas. Forced expression of HIF $1 \alpha$, unlike HIF $2 \alpha$, does not antagonize pVHL's tumor-suppressor activity in nude mouse experiments (Maranchie et al. 2002; Raval et al. 2005; Biswas et al. 2010; Shen et al. 2011). Interestingly, HIF $1 \alpha$ resides on chromosome $14 \mathrm{q}$, which is often deleted in clear cell renal cell carcinoma, and many clear cell renal carcinoma lines have 
sustained homozygous deletions that specifically inactivate HIF $1 \alpha$ such that they solely produce HIF $2 \alpha$ (Shen et al. 2011). Restoring HIF $1 \alpha$ expression in such cell lines suppresses tumor growth, whereas eliminating HIF $1 \alpha$ in lines that retain a wild-type $H I F 1 \alpha$ allele promotes tumor growth (Shen et al. 2011). Intragenic HIFl $\alpha$ mutations have rarely been identified in clear cell renal cancers and, when tested, have uniformly been loss of function (Morris et al. 2009; Dalgliesh et al. 2010; Shen et al. 2011). Moreover, the appearance of HIF2 $\alpha$, and apparent loss of HIF $1 \alpha$, in preneoplastic renal lesions in VHL patients correlates with worsening cellular atypia and signs of impending transformation (Mandriota et al. 2002; Schietke et al. 2012). Interestingly, genetic ablation of $H I F 1 \alpha$ worsens the renal pathology associated with papillary renal cancers driven by fumarate hydratase loss in the mouse, providing a precedent for HIF $1 \alpha$ as a renal cancer suppressor (Adam et al. 2011).

Most $14 \mathrm{q}$ deleted clear cell renal cancers, in contrast to clear cell renal carcinoma cell lines, retain one HIFI $\alpha$ allele and the remaining $H I F 1 \alpha$ allele is usually wildtype. It is not yet clear whether the homozygous HIFl $\alpha$ deletions detected in cell lines occurred in vivo, possibly associated with disease progression, or were selected for ex vivo. Nor is it clear whether HIFl $\alpha$ can act as a haploinsufficient tumor suppressor in vivo.

Nonetheless, these findings suggest that HIF $1 \alpha$ and HIF $2 \alpha$ have nonidentical, and probably opposing, roles in clear cell renal cancer (Keith et al. 2012). In further support of this conclusion, HIF $2 \alpha$ has been shown in the renal carcinoma setting to cooperate with $\mathrm{c}-\mathrm{Myc}$ and to suppress p53, whereas HIF $1 \alpha$ has the opposite effects (Keith et al. 2012). These different roles presumably reflect differences in their ability to activate different HIF target genes, for the reasons cited above, as well as differences with respect to other noncanonical functions.

\section{TARGETING HIF2-RESPONSIVE GENE PRODUCTS WITH SMALL MOLECULES}

Drugs exist for a number of HIF2-responsive gene products suspected of playing a role in clear cell renal carcinogenesis including VEGF, PDGF B, c-Met, TGF $\alpha$ (ligand for EGFR), cyclin D1, and both SDF1 and its receptor, CXCR4. Among epithelial cancers, clear cell renal carcinomas have the highest VEGF levels, presumably driven by $\mathrm{pVHL}$ loss and HIF2 deregulation. Moreover, the induction of VEGF early during the evolution of clear cell renal carcinomas probably minimizes the selection pressure to activate alternative angiogenic factors. Perhaps for this reason, clear cell carcinomas have proven to be particularly sensitive to drugs that inhibit VEGF or its receptor, kinase insert domain receptor (KDR). Six such agents have now been approved by the U.S. Federal Drug Administration (FDA) for this indication (Table 1).

Platelet-derived growth factor subunit B (PDGFB) acts to support vascular pericytes, and immature vessels without pericyte coverage are more sensitive to VEGF withdrawal than are mature vessels (Benjamin and Keshet 1997; Benjamin et al. 1998, 1999). Many of the currently available KDR inhibitors also inhibit the PDGF receptor, which could theoretically enhance their activity. On the other hand, PDGF receptor inhibitors have not proven to be active in clear cell renal carcinoma, either alone or added to VEGF inhibitors (Polite et al. 2006; Vuky et al. 2006; Hainsworth et al. 2007; Ryan et al. 2011).

HIF2, in ways that are still not completely understood, enhances signaling by c-Met and its ligand hepatocyte growth factor (HGF) (Koochekpour et al. 1999; Pennacchietti et al. 2003; Nakaigawa et al. 2006), and pVHLdefective renal carcinoma cells are hypersensitive to cMet depletion with small interfering RNAs (siRNAs) (Bommi-Reddy et al. 2008). Cabozantinib, which inhibits KDR and c-Met, is highly active against clear cell renal carcinoma, including in patients who have failed multiple VEGF inhibitors (Choueiri et al. 2015, 2016). It is unclear, however, whether this is truly because of its ability to inhibit c-Met. It is formally possible, for example, that cabozantinib is simply a better KDR inhibitor in vivo than other drugs in this class.

Clear cell renal carcinomas express high level of the HIF2-responsive growth factor transforming growth factor $\alpha(\mathrm{TGF}-\alpha)$ as well as its receptor, epidermal growth factor receptor (EGFR) (Uhlman et al. 1995; Ramp et al. 1997; Knebelmann et al. 1998; de Paulsen et al. 2001; Merseburger et al. 2005; Smith et al. 2005). HIF2 promotes the translation of EGFR (Franovic et al. 2007; Uniacke et al. 2012), whereas pVHL has been reported to promote the endocytosis and degradation of EGFR (Zhou and Yang 2011; Uniacke et al. 2012). Although clear cell renal carcinoma lines are sensitive to EGFR inactivation in mouse models, EGFR inhibitors have thus far been essentially inactive against clear cell renal carcinoma patients. The reason for this conundrum is unclear, but it could be due, at least partly, to selection for EGFR dependence ex vivo during cell line selection and propagation.

The cells giving rise to clear cell renal carcinoma are unusual in that HIF $2 \alpha$ can induce cyclin D1 in this

Table 1. List of genes associated with methylation imprint, which are confirmed by knockout mouse studies

\begin{tabular}{llllr}
\hline Agent & U.S. Brand Name & Company & Description & Approval Year for Kidney Cancer \\
\hline Sorafenib & Nexavar & Onyx/Bayer & TKI & 2005 \\
Sunitinib & Sutent & Pfizer & TKI & 2006 \\
Bevacizumab & Avastin & Genentech & Anti-VEGF Ab & 2009 \\
Pazopanib & Votrient & GlaxoSmithKline & TKI & 2009 \\
Axitinib & Inlyta & Pfizer & TKI & 2012 \\
Cabozantinib & Cabometyx, Cometriq & Exelixis & TKI & 2016 \\
\hline
\end{tabular}


context, whereas HIF and hypoxia usually down-regulate cyclin D1 (Bindra et al. 2002; Zatyka et al. 2002; Baba et al. 2003). Moreover, pVHL-defective clear cell renal carcinoma cells appear to be more dependent on cdk6 than isogenic cells in which pVHL has been restored and are sensitive to shRNA-mediated depletion of cyclin D1 (Bommi-Reddy et al. 2008; Zhang et al. 2013). Finally, a human polymorphism linked to the risk of clear cell renal cell carcinoma alters the binding of HIF $2 \alpha$ to a cyclin $D$ transcriptional enhancer element (Schodel et al. 2012). It will be of interest to see if newer, more specific, cdk4/6 inhibitors, such as palbociclib and abemaciclib, are active in this disease.

CXCR4 has been implicated in the maintenance of clear cell renal carcinoma cancer-initiating cells, in tumor cell invasion and metastasis, and in mobilization of myeloid-derived suppressor cells that have been linked to resistance to VEGF blockade (Staller et al. 2003; Zagzag et al. 2005; Pan et al. 2006; Struckmann et al. 2008; Gassenmaier et al. 2013; Panka et al. 2013; Vanharanta et al. 2013; Micucci et al. 2015). A number of CXCR4 inhibitors have been proven safe in man, and clear cell renal carcinoma trials are contemplated.

\section{DEVELOPMENT OF DIRECT HIF2 ANTAGONISTS}

In theory targeting HIF2 itself would be more efficacious than targeting any one HIF2-responsive gene product. Unfortunately, however, DNA-binding transcription factors have classically been viewed as undruggable by the pharmaceutical industry. The one exception to this rule has been the steroid hormone receptors, which have ligand-binding hydrophobic pockets that can serve as an entry point for drug design.

Fortunately, pioneering work by Rick Bruick and Kevin Gardner identified a potentially druggable hydrophobic pocket in the HIF2 $\alpha$ PAS B domain (Scheuermann et al.
2009, 2013; Rogers et al. 2013). Moreover, these investigators identified chemical matter that can bind to this pocket and allosterically prevent dimer formation between HIF $2 \alpha$ and aryl hydrocarbon receptor nuclear translocator (ARNT) (Scheuermann et al. 2009, 2013; Rogers et al. 2013). These discoveries formed the basis for medicinal chemistry efforts at Peloton Therapeutics that led to the HIF2 $\alpha$ inhibitor PT2385 and the highly related tool compound PT2399 (Chen et al. 2016; Cho et al. 2016; Wallace et al. 2016).

PT2385 and PT2399 inhibit HIF2 $\alpha$-ARNT1 dimerization and HIF $2 \alpha$-dependent transcription in cells at highnanomolar/low-micromolar concentrations (Chen et al. 2016; Cho et al. 2016; Wallace et al. 2016) (Fig. 2). Importantly, these effects are highly specific because these two compounds do not affect HIF1 (Chen et al. 2016; Cho et al. 2016; Wallace et al. 2016). PT2399 also inhibits the growth of pVHL-defective clear cell renal carcinoma cells in soft agar assays, in subcutaneous and orthotopic xenograft assays, and in lung colonization assays aimed at modeling established pulmonary metastases (Chen et al. 2016; Cho et al. 2016; Wallace et al. 2016). These effects of PT2399 on transcription and tumor growth are on-target because they can be reversed with HIF $2 \alpha$ variants that contain single missense mutations that prevent them from binding to PT2399 (Chen et al. 2016; Cho et al. 2016). PT2385 and PT2399 are also active in patient-derived xenograft models, including some models that are relatively resistant to the KDR inhibitor sunitinib (Chen et al. 2016; Cho et al. 2016; Wallace et al. 2016). Based on these data PT2385 has entered human clinical trials, with promising early signs of activity (Chen et al. 2016).

Nonetheless, it is already clear that some pVHL-defective clear cell renal carcinoma lines and patient-derived xenografts are resistant to PT2385/PT2399, as are some patients (Chen et al. 2016; Cho et al. 2016). This is because of, at least in part, previously unappreciated variability with respect to HIF $2 \alpha$ dependence among

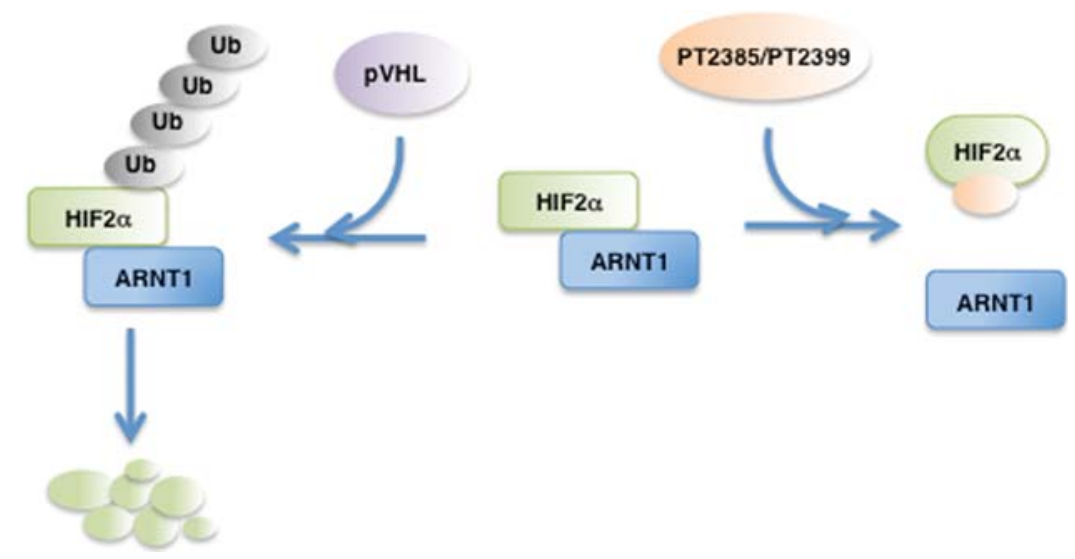

Figure 2. Control of hypoxia-inducible factor 2 (HIF2) by von Hippel-Lindau tumor-suppressor protein (pVHL) and PT2385/ PT2399. In the presence of oxygen pVHL binds directly to the HIF $2 \alpha$ subunit and polyubiquitylates it, thereby targeting HIF2 $\alpha$ for proteasomal degradation. In pVHL-defective cells HIF2 accumulates inappropriately. PT2385 and the related compound PT2399 bind directly to HIF $2 \alpha$ and induce an allosteric change that prevents HIF2 $\alpha$ from binding to its obligate partner, aryl hydrocarbon receptor nuclear translocator 1 (ARNT1). 
pVHL-defective clear cell renal carcinoma lines and tumors and suggests that predictive biomarkers will be needed to optimize the use of such agents in the clinic (Chen et al. 2016; Cho et al. 2016). In the preclinical models the most sensitive renal carcinoma lines and patient-derived xenografts had the highest HIF2 $\alpha$ levels, suggesting these two properties are linked (Chen et al. 2016; Cho et al. 2016). Conversely, the presence of p53 mutations predicts for resistance (Chen et al. 2016; Cho et al. 2016). Although p53 mutations are relatively rare in primary clear cell renal carcinomas, their true prevalence in metastatic disease is not known. Moreover, it is possible that p53 mutations are selected for by prior therapy, including therapy with VEGF inhibitors.

\section{CONCLUSION}

Biallelic inactivation of the $V H L$ tumor-suppressor gene is the most frequent initiating, or truncal, event in clear cell renal carcinoma. The VHL gene product, pVHL, is the substrate recognition subunit of a ubiquitin ligase that targets HIF $\alpha$ subunits for proteasomal degradation when oxygen is present. Loss of pVHL leads the inappropriate accumulation of active HIF1 and HIF2. HIF2 drives clear cell renal carcinogenesis, and drugs that inhibit the HIF2-responsive gene product VEGF are now cornerstones of kidney cancer therapy. HIF $2 \alpha$ was recently found to have a druggable hydrophobic pocket, and a first-generation HIF $2 \alpha$ inhibitor that blocks its dimerization with ARNT, and hence inactivates HIF2, has now entered the clinic based on promising preclinical data. Nonetheless, HIF $2 \alpha$ dependence among clear cell renal carcinomas appears to be heterogeneous. Moreover, p53 pathway mutations confer resistance to HIF2 $\alpha$ antagonists in preclinical models. These two observations imply the need for predictive biomarkers to optimize the use of HIF $2 \alpha$ antagonists in the clinic.

\section{ACKNOWLEDGMENTS}

W.G.K. is supported by grants from the National Institutes of Health and is a Howard Hughes Medical Institute (HHMI) investigator. He is a paid consultant for, and has equity in, Peloton Therapeutics.

\section{REFERENCES}

Adam J, Hatipoglu E, O'Flaherty L, Ternette N, Sahgal N, Lockstone H, Baban D, Nye E, Stamp GW, Wolhuter K, et al. 2011. Renal cyst formation in Fh1-deficient mice is independent of the Hif/Phd pathway: Roles for fumarate in KEAP1 succination and Nrf2 signaling. Cancer Cell 20: 524-537.

Albers J, Rajski M, Schonenberger D, Harlander S, Schraml P, von Teichman A, Georgiev S, Wild PJ, Moch H, Krek W, et al. 2013. Combined mutation of Vhl and Trp53 causes renal cysts and tumours in mice. EMBO Mol Med 5: 949-964.

Baba M, Hirai S, Yamada-Okabe H, Hamada K, Tabuchi H, Kobayashi K, Kondo K, Yoshida M, Yamashita A, Kishida T, et al. 2003. Loss of von Hippel-Lindau protein causes cell density dependent deregulation of CyclinD1 expression through hypoxia-inducible factor. Oncogene 22: 2728-2738.
Benjamin LE, Keshet E. 1997. Conditional switching of vascular endothelial growth factor (VEGF) expression in tumors: Induction of endothelial cell shedding and regression of hemangioblastoma-like vessels by VEGF withdrawal. Proc Natl Acad Sci 94: 8761-8766.

Benjamin LE, Hemo I, Keshet E. 1998. A plasticity window for blood vessel remodelling is defined by pericyte coverage of the preformed endothelial network and is regulated by PDGFB and VEGF. Development 125: 1591-1598.

Benjamin LE, Golijanin D, Itin A, Pode D, Keshet E. 1999. Selective ablation of immature blood vessels in established human tumors follows vascular endothelial growth factor withdrawal. J Clin Invest 103: 159-165.

Beroukhim R, Brunet JP, Di Napoli A, Mertz KD, Seeley A, Pires MM, Linhart D, Worrell RA, Moch H, Rubin MA, et al. 2009. Patterns of gene expression and copy-number alterations in von Hippel-Lindau disease-Associated and sporadic clear cell carcinoma of the kidney. Cancer Res 69: 4674-4681.

Bindra RS, Vasselli JR, Stearman R, Linehan WM, Klausner RD. 2002. VHL-mediated hypoxia regulation of cyclin D1 in renal carcinoma cells. Cancer Res 62: 3014-3019.

Biswas S, Troy H, Leek R, Chung YL, Li JL, Raval RR, Turley H, Gatter K, Pezzella F, Griffiths JR, et al. 2010. Effects of HIF- $1 \alpha$ and HIF $2 \alpha$ on growth and metabolism of clear-cell renal cell carcinoma 786-0 xenografts. J Oncol 2010: 757908.

Bommi-Reddy A, Almeciga I, Sawyer J, Geisen C, Li W, Harlow E, Kaelin WG Jr, Grueneberg DA. 2008. Kinase requirements in human cells: III. Altered kinase requirements in $\mathrm{VHL}^{-/-}$cancer cells detected in a pilot synthetic lethal screen. Proc Natl Acad Sci 105: 16484-16489.

Cancer Genome Atlas Research Network. 2013. Comprehensive molecular characterization of clear cell renal cell carcinoma. Nature 499: 43-49.

Chen W, Hill H, Christie A, Kim MS, Holloman E, Pavia-Jimenez A, Homayoun F, Ma Y, Patel N, Yell P, et al. 2016. Targeting renal cell carcinoma with a HIF-2 antagonist. $\mathrm{Na}$ ture 539: $112-117$

Cho H, Du X, Rizzi JP, Liberzon E, Chakraborty AA, Gao W, Carvo I, Signoretti S, Bruick R, Josey JA, et al. 2016. Ontarget efficacy of a HIF $2 \alpha$ antagonist in preclinical kidney cancer models. Nature 539: 107-111.

Choueiri TK, Escudier B, Powles T, Mainwaring PN, Rini BI, Donskov F, Hammers H, Hutson TE, Lee JL, Peltola K, et al. 2015. Cabozantinib versus everolimus in advanced renal-cell carcinoma. N Engl J Med 373: 1814-1823.

Choueiri TK, Escudier B, Powles T, Tannir NM, Mainwaring PN, Rini BI, Hammers HJ, Donskov F, Roth BJ, Peltola K, et al. 2016. Cabozantinib versus everolimus in advanced renal cell carcinoma (METEOR): Final results from a randomised, open-label, phase 3 trial. Lancet Oncol 17: 917-927.

Dalgliesh GL, Furge K, Greenman C, Chen L, Bignell G, Butler A, Davies H, Edkins S, Hardy C, Latimer C, et al. 2010. Systematic sequencing of renal carcinoma reveals inactivation of histone modifying genes. Nature 463: 360-363.

Davidowitz E, Schoenfeld A, Burk R. 2001. VHL induces renal cell differentiation and growth arrest through integration of cell-cell and cell-extracellular matrix signaling. Mol Cell Biol 21: $865-874$.

de Paulsen N, Brychzy A, Fournier M-C, Klausner RD, Gnarra JR, Pause A, Lee S. 2001. Role of transforming growth factor$\alpha$ in $\mathrm{VHL}^{-}{ }^{-}$clear cell renal carcinoma cell proliferation: A possible mechanism coupling von Hippel-Lindau tumor suppressor inactivation and tumorigenesis. Proc Natl Acad Sci 13: $1387-1392$.

Dondeti VR, Wubbenhorst B, Lal P, Gordan JD, D'Andrea K, Attiyeh EF, Simon MC, Nathanson KL. 2012. Integrative genomic analyses of sporadic clear cell renal cell carcinoma define disease subtypes and potential new therapeutic targets. Cancer Res 72: 112-121.

Duns G, Hofstra RM, Sietzema JG, Hollema H, van Duivenbode I, Kuik A, Giezen C, Jan O, Bergsma JJ, Bijnen H, et al. 2012. Targeted exome sequencing in clear cell renal cell carcinoma 
tumors suggests aberrant chromatin regulation as a crucial step in ccRCC development. Hum Mutat 33: 1059-1062.

Fisher R, Horswell S, Rowan A, Salm MP, de Bruin EC, Gulati S, McGranahan N, Stares M, Gerlinger M, Varela I, et al. 2014. Development of synchronous VHL syndrome tumors reveals contingencies and constraints to tumor evolution. $\mathrm{Ge}$ nome Biol 15: 433.

Franovic A, Gunaratnam L, Smith K, Robert I, Patten D, Lee S. 2007. Translational up-regulation of the EGFR by tumor hypoxia provides a nonmutational explanation for its overexpression in human cancer. Proc Natl Acad Sci 104: $13092-13097$

Frew IJ, Thoma CR, Georgiev S, Minola A, Hitz M, Montani M, Moch H, Krek W. 2008. pVHL and PTEN tumour suppressor proteins cooperatively suppress kidney cyst formation. EMBO J 27: $1747-1757$.

Gassenmaier M, Chen D, Buchner A, Henkel L, Schiemann M, Mack B, Schendel DJ, Zimmermann W, Pohla H. 2013. CXC chemokine receptor 4 is essential for maintenance of renal cell carcinoma-initiating cells and predicts metastasis. Stem Cells 31: 1467-1476.

Gerlinger M, Rowan AJ, Horswell S, Larkin J, Endesfelder D, Gronroos E, Martinez P, Matthews N, Stewart A, Tarpey P, et al. 2012. Intratumor heterogeneity and branched evolution revealed by multiregion sequencing. $N$ Engl J Med 366: 883 892.

Gerlinger M, Horswell S, Larkin J, Rowan AJ, Salm MP, Varela I, Fisher R, McGranahan N, Matthews N, Santos CR, et al. 2014. Genomic architecture and evolution of clear cell renal cell carcinomas defined by multiregion sequencing. Nat $\mathrm{Ge}-$ net 46: 225-233.

Gnarra J, Ward J, Porter F, Wagne J, Devor D, Grinberg A, Emmert-Buck M, Westphal H, Klausner R, Linehan W. 1997. Defective placental vasculogenesis causes embryonic lethality in VHL-deficient mice. Proc Natl Acad Sci 94: 9102-9107.

Gordan JD, Lal P, Dondeti VR, Letrero R, Parekh KN, Oquendo CE, Greenberg RA, Flaherty KT, Rathmell WK, Keith B, et al. 2008. HIF- $\alpha$ effects on c-Myc distinguish two subtypes of sporadic VHL-deficient clear cell renal carcinoma. Cancer Cell 14: 435-446.

Guo G, Gui Y, Gao S, Tang A, Hu X, Huang Y, Jia W, Li Z, He M, Sun L, et al. 2011. Frequent mutations of genes encoding ubiquitin-mediated proteolysis pathway components in clear cell renal cell carcinoma. Nat Genet 44: 17-19.

Hainsworth JD, Spigel DR, Sosman JA, Burris HA III, Farley C, Cucullu H, Yost K, Hart LL, Sylvester L, Waterhouse DM, et al. 2007. Treatment of advanced renal cell carcinoma with the combination bevacizumab/erlotinib/imatinib: A phase I/ II trial. Clin Genitourin Cancer 5: 427-432.

Hu C-J, Wang L-Y, Chodosh LA, Keith B, Simon MC. 2003 Differential roles of hypoxia-inducible factor 1a (HIF-1a) and HIF-2a in hypoxic gene regulation. Mol Cell Biol 23: $9361-$ 9374.

Iliopoulos O, Kibel A, Gray S, Kaelin WG. 1995. Tumor suppression by the human von Hippel-Lindau gene product. Nat Med 1: 822-826.

Kaelin WG. 2002. Molecular basis of the VHL hereditary cancer syndrome. Nat Rev Cancer 2: 673-682.

Kaelin WG Jr. 2007. von Hippel-Lindau disease. Annu Rev Pathol 2: 145-173.

Kaelin WG Jr. 2008. The von Hippel-Lindau tumour suppressor protein: $\mathrm{O}_{2}$ sensing and cancer. Nat Rev Cancer 8: 865-873.

Kaelin WG Jr, Ratcliffe PJ. 2008. Oxygen sensing by metazoans: The central role of the HIF hydroxylase pathway. $\mathrm{Mol}$ Cell 30: 393-402.

Kapitsinou PP, Liu Q, Unger TL, Rha J, Davidoff O, Keith B, Epstein JA, Moores SL, Erickson-Miller CL, Haase VH. 2010. Hepatic HIF-2 regulates erythropoietic responses to hypoxia in renal anemia. Blood 116: 3039-3048.

Keith B, Johnson RS, Simon MC. 2012. HIF1 $\alpha$ and HIF2 $\alpha$ : Sibling rivalry in hypoxic tumour growth and progression. Nat Rev Cancer 12: 9-22.
Kim WY, Safran M, Buckley MR, Ebert BL, Glickman J, Bosenberg M, Regan M, Kaelin WG Jr. 2006. Failure to prolyl hydroxylate hypoxia-inducible factor $\alpha$ phenocopies VHL inactivation in vivo. EMBO J 25: 4650-4662.

Knebelmann B, Ananth S, Cohen H, Sukhatme V. 1998. Transforming growth factor $\alpha$ is a target for the von Hippel-Lindau tumor suppressor. Cancer Res 58: 226-231.

Kondo K, Klco J, Nakamura E, Lechpammer M, Kaelin WG. 2002. Inhibition of HIF is necessary for tumor suppression by the von Hippel-Lindau protein. Cancer Cell 1: 237-246.

Kondo K, Kim WY, Lechpammer M, Kaelin WG Jr. 2003. Inhibition of HIF $2 \alpha$ is sufficient to suppress pVHL-defective tumor growth. PLoS Biol 1: 439-444.

Koochekpour S, Jeffers M, Wang P, Gong C, Taylor G, Roessler L, Stearman R, Vasselli J, Stetler-Stevenson W, Kaelin WJ, et al. 1999. The von Hippel-Lindau tumor suppressor gene inhibits hepatocyte growth factor/scatter factor-induced invasion and branching morphogenesis in renal carcinoma cells. Mol Cell Biol 19: 5902-5912.

Li L, Zhang L, Zhang X, Yan Q, Minamishima YA, Olumi AF, Mao M, Bartz S, Kaelin WG Jr. 2007. Hypoxia-inducible factor linked to differential kidney cancer risk seen with type 2A and type 2B VHL mutations. Mol Cell Biol 27: 5381-5392.

Lieubeau-Teillet B, Rak J, Jothy S, Iliopoulos O, Kaelin W, Kerbel R. 1998. von Hippel-Lindau gene-mediated growth suppression and induction of differentiation in renal cell carcinoma cells grown as multicellular tumor spheroids. Cancer Res 58: 4957-4962.

Lubensky IA, Gnarra JR, Bertheau P, Walther MM, Linehan WM, Zhuang Z. 1996. Allelic deletions of the VHL gene detected in multiple microscopic clear cell renal lesions in von Hippel-Lindau disease patients. Am J Pathol 149: 2089-2094.

Maher E, Kaelin WG. 1997. von Hippel-Lindau disease. Medicine 76: 381-391.

Mandriota SJ, Turner KJ, Davies DR, Murray PG, Morgan NV, Sowter HM, Wykoff CC, Maher ER, Harris AL, Ratcliffe PJ, et al. 2002. HIF activation identifies early lesions in VHL kidneys: Evidence for site-specific tumor suppressor function in the nephron. Cancer Cell 1: 459-468.

Maranchie JK, Vasselli JR, Riss J, Bonifacino JS, Linehan WM, Klausner RD. 2002. The contribution of VHL substrate binding and HIF1- $\alpha$ to the phenotype of VHL loss in renal cell carcinoma. Cancer Cell 1: 247-255.

Merseburger AS, Hennenlotter J, Simon P, Kruck S, Koch E, Horstmann M, Kuehs U, Kufer R, Stenzl A, Kuczyk MA. 2005. Membranous expression and prognostic implications of epidermal growth factor receptor protein in human renal cell cancer. Anticancer Res 25: 1901-1907.

Micucci C, Matacchione G, Valli D, Orciari S, Catalano A. 2015. HIF2 $\alpha$ is involved in the expansion of CXCR4-positive cancer stem-like cells in renal cell carcinoma. Br J Cancer 113: $1178-1185$.

Montani M, Heinimann K, von Teichman A, Rudolph T, Perren A, Moch H. 2010. VHL-gene deletion in single renal tubular epithelial cells and renal tubular cysts: Further evidence for a cyst-dependent progression pathway of clear cell renal carcinoma in von Hippel-Lindau disease. Am J Surg Pathol 34: $806-815$

Morris MR, Hughes DJ, Tian YM, Ricketts CJ, Lau KW, Gentle D, Shuib S, Serrano-Fernandez P, Lubinski J, Wiesener MS, et al. 2009. Mutation analysis of hypoxia-inducible factors HIF1A and HIF2A in renal cell carcinoma. Anticancer Res 29: $4337-4343$.

Nakaigawa N, Yao M, Baba M, Kato S, Kishida T, Hattori K, Nagashima Y, Kubota Y. 2006. Inactivation of von HippelLindau gene induces constitutive phosphorylation of MET protein in clear cell renal carcinoma. Cancer Res 66: 3699-3705.

Pan J, Mestas J, Burdick MD, Phillips RJ, Thomas GV, Reckamp K, Belperio JA, Strieter RM. 2006. Stromal derived factor-1 (SDF-1/CXCL12) and CXCR4 in renal cell carcinoma metastasis. Mol Cancer 5: 56. 
Panka DJ, Liu Q, Geissler AK, Mier JW. 2013. Effects of HDM2 antagonism on sunitinib resistance, p53 activation, SDF-1 induction, and tumor infiltration by $\mathrm{CD} 11 \mathrm{~b}^{+} / \mathrm{Gr}-1^{+}$myeloid derived suppressor cells. Mol Cancer 12: 17.

Pause A, Lee S, Lonergan KM, Klausner RD. 1998. The von Hippel-Lindau tumor suppressor gene is required for cell cycle exit upon serum withdrawal. Proc Natl Acad Sci 95: 993-998.

Pena-Llopis S, Vega-Rubin-de-Celis S, Liao A, Leng N, PaviaJimenez A, Wang S, Yamasaki T, Zhrebker L, Sivanand S, Spence P, et al. 2012. BAP1 loss defines a new class of renal cell carcinoma. Nat Genet 44: 751-759.

Pennacchietti S, Michieli P, Galluzzo M, Mazzone M, Giordano S, Comoglio PM. 2003. Hypoxia promotes invasive growth by transcriptional activation of the met protooncogene. Cancer Cell 3: 347-361.

Polite BN, Desai AA, Manchen B, Stadler WM. 2006. Combination therapy of imatinib mesylate and interferon- $\alpha$ demonstrates minimal activity and significant toxicity in metastatic renal cell carcinoma: Results of a single-institution phase II trial. Clin Genitourin Cancer 4: 275-280.

Purdue MP, Johansson M, Zelenika D, Toro JR, Scelo G, Moore LE, Prokhortchouk E, Wu X, Kiemeney LA, Gaborieau V, et al. 2011. Genome-wide association study of renal cell carcinoma identifies two susceptibility loci on 2p21 and 11q13.3. Nat Genet 43: 60-65.

Ramp U, Jaquet K, Reinecke P, Schardt C, Friebe U, Nitsch T, Marx N, Gabbert HE, Gerharz CD. 1997. Functional intactness of stimulatory and inhibitory autocrine loops in human renal carcinoma cell lines of the clear cell type. J Urol 157: $2345-2350$.

Rankin EB, Biju MP, Liu Q, Unger TL, Rha J, Johnson RS, Simon MC, Keith B, Haase VH. 2007. Hypoxia-inducible factor-2 (HIF-2) regulates hepatic erythropoietin in vivo. $J$ Clin Invest 117: 1068-1077.

Rankin EB, Rha J, Unger TL, Wu CH, Shutt HP, Johnson RS, Simon MC, Keith B, Haase VH. 2008. Hypoxia-inducible factor-2 regulates vascular tumorigenesis in mice. Oncogene 27: $5354-5358$.

Rankin EB, Rha J, Selak MA, Unger TL, Keith B, Liu Q, Haase VH. 2009. HIF-2 regulates hepatic lipid metabolism. Mol Cell Biol 29: 4527-4538.

Raval RR, Lau KW, Tran MG, Sowter HM, Mandriota SJ, Li JL, Pugh CW, Maxwell PH, Harris AL, Ratcliffe PJ. 2005. Contrasting properties of hypoxia-inducible factor 1 (HIF-1) and HIF-2 in von Hippel-Lindau-associated renal cell carcinoma. Mol Cell Biol 25: 5675-5686.

Rogers JL, Bayeh L, Scheuermann TH, Longgood J, Key J, Naidoo J, Melito L, Shokri C, Frantz DE, Bruick RK, et al. 2013. Development of inhibitors of the PAS-B domain of the HIF- $2 \alpha$ transcription factor. $J$ Med Chem 56: 1739-1747.

Ryan CW, Vuky J, Chan JS, Chen Z, Beer TM, Nauman D. 2011. A phase II study of everolimus in combination with imatinib for previously treated advanced renal carcinoma. Invest New Drugs 29: 374-379.

Sankin A, Hakimi AA, Mikkilineni N, Ostrovnaya I, Silk MT, Liang Y, Mano R, Chevinsky M, Motzer RJ, Solomon SB, et al. 2014. The impact of genetic heterogeneity on biomarker development in kidney cancer assessed by multiregional sampling. Cancer Med 3: 1485-1492.

Scheuermann TH, Tomchick DR, Machius M, Guo Y, Bruick RK, Gardner KH. 2009. Artificial ligand binding within the HIF $2 \alpha$ PAS-B domain of the HIF2 transcription factor. Proc Natl Acad Sci 106: 450-455.

Scheuermann TH, Li Q, Ma HW, Key J, Zhang L, Chen R, Garcia JA, Naidoo J, Longgood J, Frantz DE, et al. 2013. Allosteric inhibition of hypoxia inducible factor-2 with small molecules. Nat Chem Biol 9: 271-276.

Schietke RE, Hackenbeck T, Tran M, Gunther R, Klanke B, Warnecke CL, Knaup KX, Shukla D, Rosenberger C, Koesters R, et al. 2012. Renal tubular HIF-2 $\alpha$ expression requires VHL inactivation and causes fibrosis and cysts. PLoS One 7: e31034.
Schodel J, Bardella C, Sciesielski LK, Brown JM, Pugh CW, Buckle V, Tomlinson IP, Ratcliffe PJ, Mole DR. 2012. Common genetic variants at the $11 \mathrm{q} 13.3$ renal cancer susceptibility locus influence binding of HIF to an enhancer of cyclin D1 expression. Nat Genet 44: 420-425, S421-S422.

Semenza GL. 2011. Oxygen sensing, homeostasis, and disease. $N$ Engl J Med 365: 537-547.

Shen C, Beroukhim R, Schumacher SE, Zhou J, Chang M, Signoretti S, Kaelin WG Jr. 2011. Genetic and functional studies implicate HIF1 $\alpha$ as a $14 \mathrm{q}$ kidney cancer suppressor gene. Cancer Discov 1: 222-235.

Siegel RL, Miller KD, Jemal A. 2016. Cancer statistics, 2016. CA Cancer J Clin 66: 7-30.

Smith K, Gunaratnam L, Morley M, Franovic A, Mekhail K, Lee S. 2005. Silencing of epidermal growth factor receptor suppresses hypoxia-inducible factor-2-driven $\mathrm{VHL}^{-1}$ - renal cancer. Cancer Res 65: 5221-5230.

Staller P, Sulitkova J, Lisztwan J, Moch H, Oakeley EJ, Krek W. 2003. Chemokine receptor CXCR4 downregulated by von Hippel-Lindau tumour suppressor pVHL. Nature 425: 307-311.

Struckmann K, Mertz K, Steu S, Storz M, Staller P, Krek W, Schraml P, Moch H. 2008. pVHL co-ordinately regulates CXCR4/CXCL12 and MMP2/MMP9 expression in human clear-cell renal cell carcinoma. J Pathol 214: 464-471.

Uhlman DL, Nguyen P, Manivel JC, Zhang G, Hagen K, Fraley E, Aeppli D, Niehans GA. 1995. Epidermal growth factor receptor and transforming growth factor $\alpha$ expression in papillary and nonpapillary renal cell carcinoma: Correlation with metastatic behavior and prognosis. Clin Cancer Res 1: 913-920.

Uniacke J, Holterman CE, Lachance G, Franovic A, Jacob MD, Fabian MR, Payette J, Holcik M, Pause A, Lee S. 2012. An oxygen-regulated switch in the protein synthesis machinery. Nature 486: 126-129.

Vanharanta S, Shu W, Brenet F, Hakimi AA, Heguy A, Viale A, Reuter VE, Hsieh JJ, Scandura JM, Massague J. 2013. Epigenetic expansion of VHL-HIF signal output drives multiorgan metastasis in renal cancer. Nat Med 19: 50-56.

Varela I, Tarpey P, Raine K, Huang D, Ong CK, Stephens P, Davies H, Jones D, Lin ML, Teague J, et al. 2011. Exome sequencing identifies frequent mutation of the SWI/SNF complex gene PBRM1 in renal carcinoma. Nature 469: $539-542$.

Vuky J, Isacson C, Fotoohi M, dela Cruz J, Otero H, Picozzi V, Malpass T, Aboulafia D, Jacobs A. 2006. Phase II trial of imatinib (Gleevec) in patients with metastatic renal cell carcinoma. Invest New Drugs 24: 85-88.

Wallace EM, Rizzi JP, Han G, Wehn PM, Cao Z, Du X, Cheng T, Czerwinski RM, Dixon DD, Goggin BS, et al. 2016. A smallmolecule antagonist of HIF $2 \alpha$ is efficacious in preclinical models of renal cell carcinoma. Cancer Res 76: 5491-5500.

Walther M, Lubensky I, Venzon D, Zbar B, Linehan W. 1995. Prevalence of microscopic lesions in grossly normal renal parenchyma from patients with von Hippel-Lindau disease, sporadic renal cell carcinoma and no renal disease: Clinical implications. J Urol 154: 2010-2014.

Xu X, Hou Y, Yin X, Bao L, Tang A, Song L, Li F, Tsang S, Wu $\mathrm{K}$, Wu H, et al. 2012. Single-cell exome sequencing reveals single-nucleotide mutation characteristics of a kidney tumor. Cell 148: 886-895.

Zagzag D, Krishnamachary B, Yee H, Okuyama H, Chiriboga L, Ali MA, Melamed J, Semenza GL. 2005. Stromal cell-derived factor-1 $\alpha$ and CXCR4 expression in hemangioblastoma and clear cell-renal cell carcinoma: von Hippel-Lindau loss-offunction induces expression of a ligand and its receptor. Cancer Res 65: 6178-6188.

Zatyka M, da Silva NF, Clifford SC, Morris MR, Wiesener MS, Eckardt KU, Houlston RS, Richards FM, Latif F, Maher ER. 2002. Identification of cyclin D1 and other novel targets for the von Hippel-Lindau tumor suppressor gene by expression array analysis and investigation of cyclin D1 genotype as a modifier in von Hippel-Lindau disease. Cancer Res 62: 3803-3811. 
Zhang T, Niu X, Liao L, Cho EA, Yang H. 2013. The contributions of HIF-target genes to tumor growth in RCC. PLoS One 8: e80544.

Zhou L, Yang H. 2011. The von Hippel-Lindau tumor suppressor protein promotes c-Cbl-independent poly-ubiquitylation and degradation of the activated EGFR. PLoS One 6: e23936.
Zhuang Z, Bertheau P, Emmert-Buck MR, Liotta L, Gnarra J, Linehan WM, Lubensky IA. 1995. A microscopic dissection technique for archival DNA analysis of specific cell populations in lesions <1 mm in size. Am J Pathol 146: 620-625.

Zimmer M, Doucette D, Siddiqui N, Iliopoulos O. 2004. Inhibition of hypoxia-inducible factor is sufficient for growth suppression of $\mathrm{VHL}^{-/-}$tumors. Mol Cancer Res 2: 89-95. 


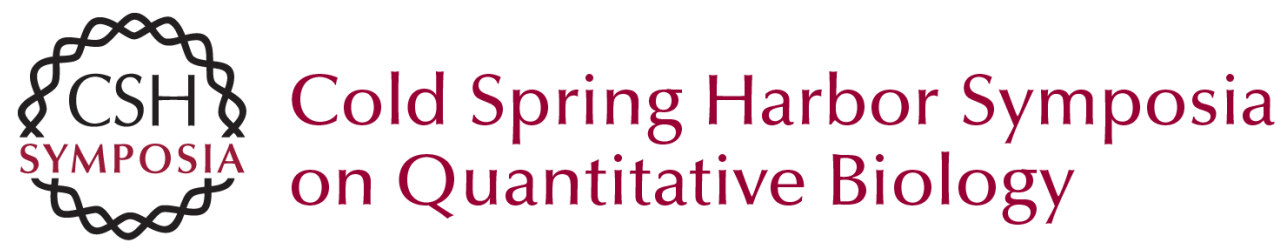

\section{Targeting HIF2 in Clear Cell Renal Cell Carcinoma}

Hyejin Cho and William G. Kaelin

Cold Spring Harb Symp Quant Biol 2016 81: 113-121 originally published online December 8, 2016

Access the most recent version at doi:10.1101/sqb.2016.81.030833

References This article cites 93 articles, 32 of which can be accessed free at: http://symposium.cshlp.org/content/81/113.full.html\#ref-list-1

Creative This article is distributed under the terms of the

Commons http://creativecommons.org/licenses/by-nc/4.0/, which permits reuse and License redistribution, except for commercial purposes, provided that the original author and source are credited.

Email Alerting Receive free email alerts when new articles cite this article - sign up in Service the box at the top right corner of the article or click here. 